\title{
CLIMATE CHANGE AND AGRICULTURE PAPER \\ Effect of household land management on cropland topsoil organic carbon storage at plot scale in a red earth soil area of South China
}

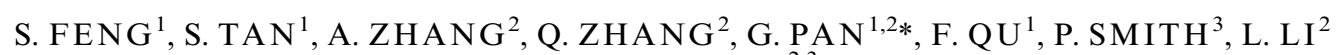 \\ AND X. ZHANG ${ }^{2,3}$ \\ ${ }^{1}$ China Centre for Land Policy Research, Nanjing Agricultural University, 1 Weigang, Nanjing 210095, China \\ ${ }^{2}$ Institute of Resource, Ecosystem and Environment of Agriculture, Nanjing Agricultural University, 1 Weigang, \\ Nanjing 210095, China \\ ${ }^{3}$ Institute of Biological and Environmental Sciences, School of Biological Sciences, University of Aberdeen, \\ 23 St Machar Drive, Aberdeen, AB24 $3 U U, U K$
}

(Revised MS received 17 December 2010; Accepted 24 February 2011; First published online 7 April 2011)

\begin{abstract}
SUMMARY
An inventory of topsoil soil organic carbon (SOC) content in household farms was performed in a village from a red earth region in Jiangxi Province, China in 2003. In this region, the farmland managed by each household is fragmented, consisting of several plots of land that are not necessarily adjacent to each other. A statistical analysis of SOC variation with land use and household management type, and with crop management practices was conducted. Plot size ranged from $0 \cdot 007$ to $0 \cdot 630$ ha with a mean of $0 \cdot 1$ ha, and SOC content ranged from 1.72 to $25 \cdot 2 \mathrm{~g} / \mathrm{kg}$, varying widely with a variety of land management and agricultural practices, arising from individual household behaviours. The mean SOC content in plot size $<0 \cdot 1$ ha was $20 \%$ lower than in plot size $\geqslant 0 \cdot 1$ ha. SOC of dry crop plots was $70 \%$ lower than that in rice paddies, and SOC of plots contracted from the village was almost double that of plots leased from other householders. Moreover, a 30\% increase in SOC was observed with green manure cultivation, and a 55\% increase under triple cropping. The difference in SOC levels between the least and most favourable cases of household land management and agricultural practice was up to $150 \%$. The results suggest that policies targeted at crop management alone may not deliver the expected SOC benefits if household land management is also not improved.
\end{abstract}

\section{INTRODUCTION}

Maintaining or increasing soil organic carbon (SOC) storage in croplands has been promoted as a "winwin'strategy by enhancing soil productivity and increasing the terrestrial $\mathrm{C}$ stock, thereby mitigating greenhouse gas (GHG) emissions in agriculture (Lal 2004a). Crop management may have great potential for mitigating climate change in agriculture through C sequestration (Smith et al. 2007). This potential,

* To whom all correspondence should be addressed. Email: gxpan1@hotmail.com; gxpan@njau.edu.cn however, will be realized only in the long-run through judicious land use and recommended management practices (Lal 2002, 2004a), whereas the choice among these may vary with the market $\mathrm{C}$ price (Lewandrowski et al. 2004; Smith \& Trines 2007).

Management practices that lead to an increase in organic inputs (biomass and manure) add $\mathrm{C}$ to the soil, improve microbial function and promote SOC accumulation. It is well known that improved crop management, such as reduced tillage and intensified cropping to enhance $\mathrm{C}$ input to the soil, favours SOC sequestration (Lal 2004a; Ogle et al. 2005). Land use changes and management, however, have significant 


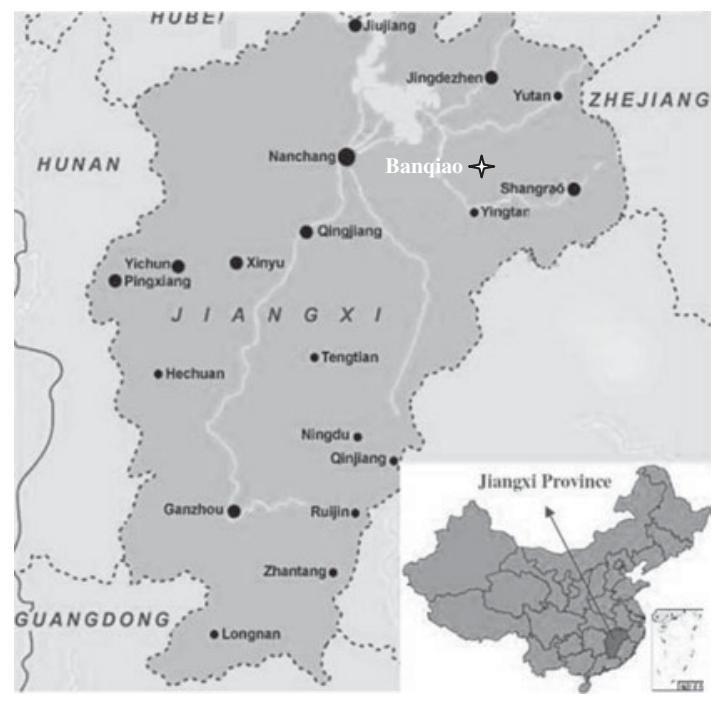

Fig. 1. Sketch map of Jiangxi Province of China showing the location of the surveyed village in yellow solid circle.

effects on world SOC storage and sequestration for potential mitigation of global climate change (Guo \& Gifford 2002; Schlamadinger et al. 2007; Smith 2008). There have been a few studies dealing with changes in SOC storage under land use and management change in croplands (Osher et al. 2003; Smith 2008).

In developing countries, constraints on land resource availability due to fragmented croplands and small-scale farm management systems impact on sustainable agriculture and food security (Simmons 1986; Niroula \& Thapa 2005; Rahman \& Rahman 2009). Soil organic matter has generally been recognized as providing a key soil function for sustainable agriculture (Smith et al. 1999; Carter 2002), and may be influenced by changes in land use intensity and land management effects (Grandy \& Robertson 2007). The potential roles of improved land use and management in enhancing $\mathrm{C}$ stocks in agricultural soils for developing countries have often been addressed (GarcíaOliva \& Masera 2004; Milne et al. 2007; Smith \& Trines 2007; Smith et al. 2007). However, a number of land policy and management barriers will probably prevent soil $\mathrm{C}$ sequestration benefits for developing countries, and proper policies for world climate and trade are required for encouraging $\mathrm{C}$ sequestration and climate change mitigation in agriculture in less developed countries (de Costa \& Sangakkara 2006; Smith \& Trines 2007; Eitzinger et al. 2010). C sequestration in croplands of developing countries will depend on the existing performance of these management practices as implemented by household farmers, but there have been very few studies on the impacts of household land management (land use, land tenure status and land fragmentation) on SOC status and sequestration potential of soils.
China has experienced profound changes in land use, land cover and land management systems over the last 50 years. Since the late 1970 s, farmland management has shifted from collective farming to a Household Responsibility System, which has resulted in small-scale household farms with intense land fragmentation (Tan et al. 2006). The impacts of farmland management on cropland soil quality and productivity have been investigated, examining the impacts of land fragmentation (Tan et al. 2008), property rights settings ( $\mathrm{Yu}$ et al. 2003) and/or household behaviours related to technology transfer (Zhang \& Xu 1996; Ou-Yang et al. 2003). With growing concerns for climate change mitigation in agriculture, sequestration of SOC in croplands may play a key role in off-setting the increasing GHG emissions in China (Lal 2004b; Pan \& Zhao 2005; Pan 2009). Changes in SOC storage and dynamics of China's croplands have been increasingly studied under land use change (Song et al. 2005; Hou et al. 2007; Li et al. 2007), fertilization practice (Wang et al. 2010), cropping and rotation (Xu et al. 2006) and tillage practice (Wang et al. 2009). While studies have indicated a significant biophysical potential for SOC sequestration in China's croplands (Lal 2002, 2004b; Pan et al. 2010), there has been little information on how, and to what extent, household farm management behaviours impact on SOC storage and the C sequestration capacity of China's croplands. This information gap limits the ability to assess the realizable contribution of SOC sequestration to the mitigation of GHGs in China in the future and weakens the development of climate policy for cropland management (Pan 2009).

The purpose of the present paper is to quantify the variation of SOC storage in household farms under different land management settings, with respect to the land tenure status, household farm size and land use, using the dataset from a farm inventory conducted in 2003. From this analysis, the aim is to provide information for policy-making for improving farm management to enhance $C$ sequestration and GHG mitigation in China's agriculture.

\section{MATERIALS AND METHODS}

\section{Household farm inventory}

An inventory of crop production and soil management at household farm scale was conducted in Banqiao village in Honghu Township, Yujiang County $\left(28^{\circ} 04^{\prime}-28^{\circ} 37^{\prime} \mathrm{N}, 116^{\circ} 41^{\prime}-117^{\circ} 09^{\prime} \mathrm{E}, 45-50 \mathrm{~m}\right.$ asl), Jiangxi Province, China (Fig. 1) in February 2003. This village is considered representative of the typical rural conditions that can be found in Northeast Jiangxi Province and in the much larger hilly area of Southeast China with rice-based production systems (Kuiper et al. 2001). The topography 
Table 1. Basic soil properties (mean \pm S.D.) of the topsoil samples $(0-150 \mathrm{~mm})(\mathrm{n}=105)$

\begin{tabular}{lc}
\hline \hline Soil property & Value \\
\hline $\mathrm{pH}\left(\mathrm{H}_{2} \mathrm{O}\right)$ & $5 \cdot 2 \pm 0 \cdot 3$ \\
$\mathrm{SOC}(\mathrm{g} / \mathrm{kg})$ & $13 \pm 6 \cdot 1$ \\
Total $\mathrm{N}(\mathrm{g} / \mathrm{kg})$ & $2 \pm 0 \cdot 7$ \\
Available $\mathrm{P}(\mathrm{mg} / \mathrm{kg})$ & $10 \pm 7 \cdot 9$ \\
Available $\mathrm{K}(\mathrm{mg} / \mathrm{kg})$ & $101 \pm 54 \cdot 0$ \\
Clay $(<0 \cdot 002 \mathrm{~mm}, \mathrm{~g} / \mathrm{kg})$ & $15 \pm 6 \cdot 8$ \\
\hline \hline
\end{tabular}

of the area is terraced Quaternary red earth. The local climate is governed by a subtropical monsoon, with a mean annual temperature of $17 \cdot 2-18 \cdot 1^{\circ} \mathrm{C}$ and annual precipitation of $1700-1800 \mathrm{~mm}$, with 0.7 of that occurring in late April-early July for the last two decades (Jiangxi Bureau of Land Management JBLM 1991). The croplands are mainly derived from red soils, which are extensive in this area. The soil type in the rice paddies was classified as hydro-agric Stagnic Anthrosols, according to Chinese Soil Taxonomy (Gong et al. 2007), and as typic Paleudults according to Soil Taxonomy (SSS-USDA 1999), whereas those for dry croplands were Inceptic Paleudults (SSS-USDA 1999). Poor soil fertility and crop productivity in this area are apparent due to degradation of the cultivated red-earth-derived soils (Zhao 2002).

The village surveyed was among those of poor agricultural productivity within the least developed economy in Jiangxi, China during 1970-90s, and most of the farmers lived on agricultural output before the survey was conducted in 2003 (Tan et al. 2008). The village had 220 households and a population of 900 in 2002 , divided into four hamlets with 113.3 ha of farmland in total, giving a land-use density of 0.15 ha per capita. Of the total farmland area, irrigated rice paddies accounted for $82 \cdot 3$ ha mostly with double rice cropping, and a further $31 \cdot 1$ ha farmland was dry croplands, mainly peanuts and vegetables plus citrus trees. The average rice yield in 2002 was $5 \cdot 1 \mathrm{t} / \mathrm{ha}$. Chemical fertilizers were commonly applied, with very limited use of farmyard manure. The land tenure system shifted to the Household Responsibility System in 1984; farmlands were allocated to households according to family size and labour force, and by considering soil quality and distance from the village.

For the survey, 15 households, managing a total of 105 plots, were randomly selected from a single hamlet within the whole area of 113.3 ha farmland affiliated with the village (Banqiao). Plot size, history of cultivation, yield and management (including land tenure status, crop rotation system, fertilization, straw return and soil fertility condition) for the past 5 years were recorded for each of the 105 plots. Rice paddies in terraces with pump irrigation have been developed since the 1960s, whereas dry land crops have persisted in the village for over 100 years. The 105 plots sampled were distributed randomly among the total farmland affiliated with the village.

\section{Soil sample collection}

Topsoil samples of all the plots associated with the 15 households surveyed were collected at a depth of 0 $150 \mathrm{~mm}$ using a soil core sampler (Eijkelkamp, The Netherlands) in late February 2003, when no crop growth was present. A composite sample was formed with three randomly selected subsamples for each plot, mixed after sampling in the field. Each sample was placed in a stainless-steel box and shipped to the laboratory within 3 days of sampling. The basic soil physical and chemical properties of the soils tested are summarized in Table 1.

\section{Soil property determination}

Soil total organic $\mathrm{C}$ and nitrogen $(\mathrm{N})$ were measured using an Elementar Vario MAX CNS Analyser (Elementar $\mathrm{GmbH}$, Germany). The determinations of soil $\mathrm{pH}\left(\mathrm{H}_{2} \mathrm{O}\right)$, available phosphorus and potassium and clay content were conducted following the protocol described by $\mathrm{Lu}$ (2000). All the extraction and determinations were performed in duplicate. The topsoil SOC values of croplands from the village surveyed and measured during the Second National Soil Survey, completed in 1985, were retrieved from the records available in the local soil survey service of Yujiang County.

\section{Statistical analysis}

Data were processed using MS-Excel 2003 in MSWindows 2003. Statistical differences in SOC between the land use types and land tenure status were tested with analysis of variance (ANOVA) using the SPSS 11.0 statistical package (SPSS 2001). Statistical significance was defined at $P<0 \cdot 05$.

\section{RESULTS}

\section{Land management status of the households surveyed}

The basic information on the land tenure and land use status of the household farmland is presented in Table 2. The mean size of the households surveyed was 4.5 persons with, on average, 0.67 ha farmland per household. The land use density of 0.15 ha per capita is larger than the mean for China as a whole, which was 0.09 ha per capita in 2004, reported by the Ministry of Land and Resources through a national land use change survey (NACOC \& FASC 1999). Of the total 105 plots surveyed, 83 were used for rice 
Table 2. General status of land management and farmland plot size (mean \pm S.D.) of the 15 households surveyed in Banqiao village

\begin{tabular}{lcc}
\hline Household farm size & $\begin{array}{c}\text { Number of plots } \\
4 \cdot 5 \pm 1 \cdot 52\end{array}$ & $\begin{array}{c}\text { Total area (ha) } \\
0 \cdot 7 \pm 0 \cdot 38\end{array}$ \\
\hline Land use & & \\
$\quad$ Rice paddy & 83 & $0 \cdot 1 \pm 0 \cdot 11$ \\
$\quad$ Dry cropland & 22 & $0 \cdot 1 \pm 0 \cdot 07$ \\
$\quad$ Land tenure & & \\
$\quad$ Contracted & 84 & $0 \cdot 1 \pm 0 \cdot 12$ \\
$\quad$ Leased & 21 & $0 \cdot 1 \pm 0 \cdot 07$ \\
Land fragmentation & & \\
$\quad<0 \cdot 1$ ha & 47 & $0 \cdot 1 \pm 0 \cdot 02$ \\
$\quad \geqslant 0 \cdot 1$ ha & 58 & $0 \cdot 2 \pm 0 \cdot 12$ \\
\hline \hline
\end{tabular}

paddies and 22 were for dry croplands, reflecting the rice-dominated agriculture in South China. Rice cultivation occupied 0.9 of the total cultivated area in Jiangxi in the late 1980s (JBLM 1991) and 0.85 of the total of the local county of Yujiang (SSOYC 1986). Reform of the land tenure system was finalized in 1985; most of the plots surveyed were used by households who contracted them directly from the village collective. However, 21 plots were leased from other households within the same village for at least one crop growing season.

As shown in Fig. 2, the plot size of the household farmlands followed a skewed distribution and ranged from 0.01 to $0.63 \mathrm{ha}$, with the majority of plots being small. The mean plot size of $0 \cdot 11$ ha for the household farmland plots surveyed was close to that of China as a whole (0.09 ha). A large degree of land fragmentation occurred in these household farmlands; 47 plots had a mean size of 0.05 ha compared to a mean size of $0 \cdot 22$ ha in the 58 plots with a plot size more than $0 \cdot 1$ ha (Table 2). Furthermore, a significantly higher degree of land fragmentation was associated with leased plots and with dry croplands (Table 2). These features of the land tenure system make it more difficult to enhance productivity and, in turn, SOC accumulation of the croplands.

\section{Variation of SOC content with land management}

Following a quasi-normal distribution (Fig. 3), which was statistically tested, the SOC contents of the 105 plots ranged from 1.7 to $25 \cdot 2 \mathrm{~g} / \mathrm{kg}$ with a mean ( \pm s.D.) of $13 \pm 6 \cdot 1 \mathrm{~g} / \mathrm{kg}$. Thus, the variability of plot SOC is significantly smaller than the variability of plot area itself. The variation of topsoil SOC content under different status of land tenure, land fragmentation and land use is presented in Fig. 4. Type of land use had profound impacts on SOC contents. The majority of the 105 plots were rice paddies with a mean SOC content of $13.95 \mathrm{~g} / \mathrm{kg}$, being significantly higher $(70 \%$ higher, on average) than the dry croplands. This is in general agreement with previous findings of much higher SOC contents in rice paddy soil than in dry croplands (Pan et al. 2004; Song et al. 2005). SOC contents were much higher in contracted than in leased plots, with the mean value of the former almost double the latter. The effect of land fragmentation on SOC content was observed to be significantly smaller, as plots $<0 \cdot 1$ ha had significantly lower SOC levels (by up to $20 \%$ on average) than those $>0.1 \mathrm{ha}$. Land fragmentation associated with farm size had an impact on SOC. For households with smaller numbers of plots, those managed by households with a greater total area of farmland showed significantly higher SOC contents (by $3.4 \mathrm{~g} / \mathrm{kg}$ on average) than those managed by households with smaller total area of farmland in 2003 (Table 3). Compared to the original SOC level in 1985, when the Household Responsibility System was newly implemented, SOC accumulation of $6 \cdot 12 \mathrm{~g} / \mathrm{kg}$ was found in plots managed by households with $>0.7$ ha total farmland area, whereas it was $1 \mathrm{~g} / \mathrm{kg}$ for plots managed by households with $<0.7$ ha total farmland. Plots managed by households with larger farm size and smaller numbers of plots were significantly richer in SOC than those managed by households with larger numbers of plots. Since the implementation of the Household Responsibility System, SOC has increased in the larger household farmlands, by over $6 \mathrm{~g} / \mathrm{kg}$ on average, compared to no significant increase in those with smaller total farmland area. The findings suggest a large interactive impact of land tenure system and land use on both SOC storage and SOC dynamics of household farmlands.

\section{Variation of topsoil SOC contents with agricultural management practices}

The area is characterized as being of low productivity for rice due to the poor soil quality and low-nutrient pools, as the soils on the red soil terrace have suffered from acidity and severe soil erosion (Zhao 2002). Previously, in order to meet the demand for higher cereal production, rice was double- or triple-cropped, and without conservation practices this has largely exhausted the soil fertility. Improved agricultural management in the area would entail a cropping system with straw return and green manure cultivation (Tan et al. 2006, 2008). As seen in Table 4, most of the plots had been cultivated with double or triple cropping of rice, with very little green manure cultivation or straw return. For dry croplands, there was a single cropping of peanuts and fruit trees with poor soil conditions, with double and triple cropping predominantly used for rice-rice and rice-rice-winter vegetable, respectively (Tan et al. 2006, 2008). While the topsoil SOC under single cropping of dry crops tended to be much lower than the double and triple 


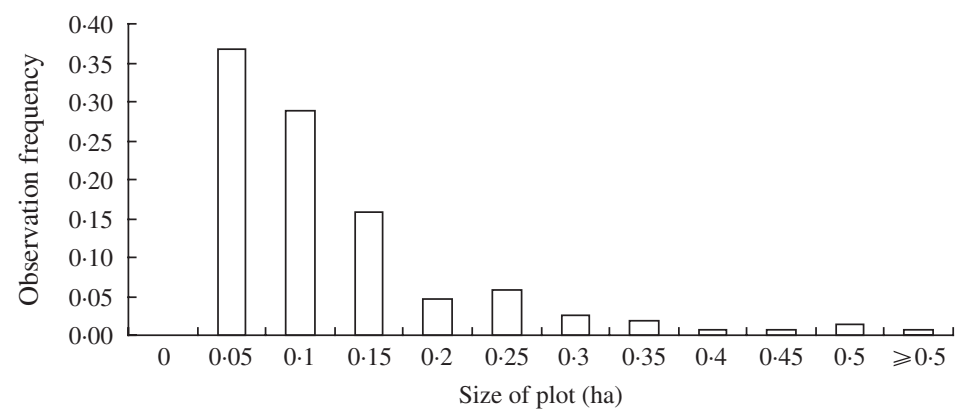

Fig. 2. Observation frequency of size distribution of the 105 plots occupied by the households surveyed.

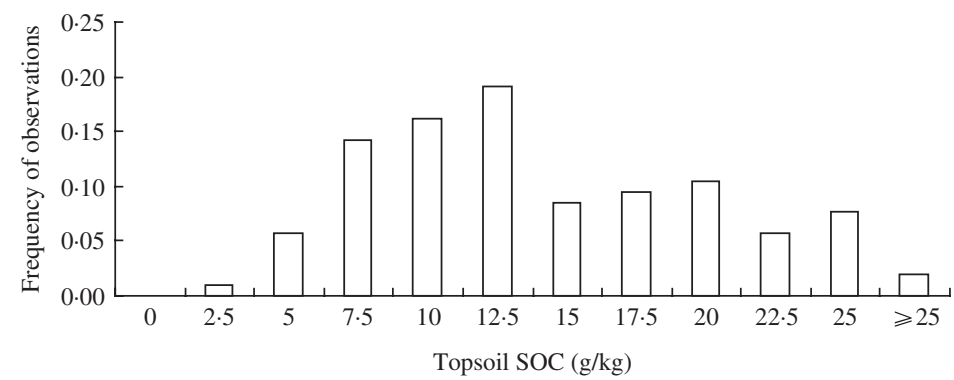

Fig. 3. Frequency distribution of topsoil organic C content of the 105 plots occupied by the households surveyed.

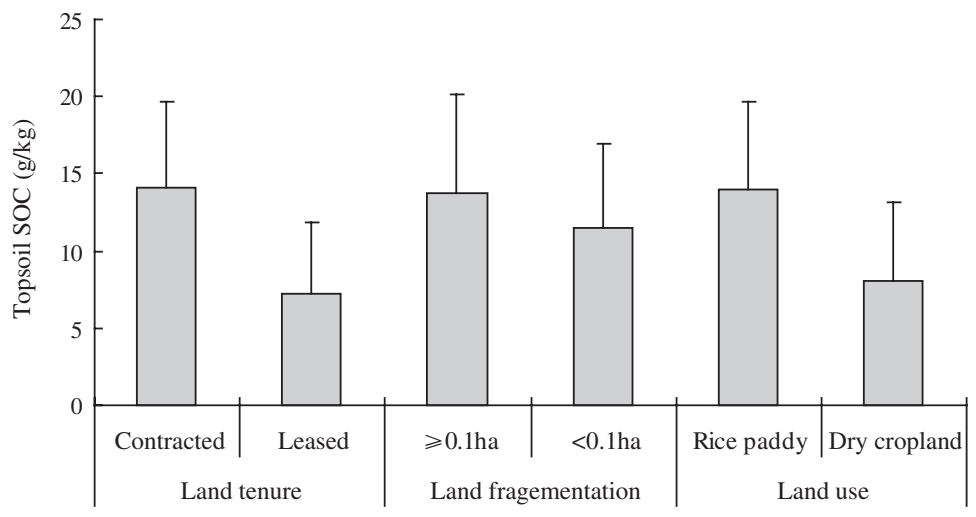

Fig. 4. Variation of topsoil organic carbon content with land management, land use and fragmentation of the 105 plots surveyed. Different capital letters above the bar indicate significant difference at $P<0 \cdot 05$ between types in a same block.

cropping with rice, there was only a small difference in SOC contents between the double- and triple-cropped plots. Cultivation of green manure crops, mainly alfalfa in this region, yielded significantly higher SOC contents than the non-green manure cultivated plots $(3.3 \mathrm{~g} / \mathrm{kg}$ more on average). However, straw return resulted in an increase in SOC by c. $5 \mathrm{~g} / \mathrm{kg}$ compared to plots without straw return. Comparatively, the effect of management practices on topsoil SOC was greatest with straw return, followed by green manure cultivation and least with rice cropping intensity.

\section{DISCUSSION}

Topsoil SOC dynamics of the surveyed farmlands

The mean ( \pm s.D.) topsoil SOC level of the village farmlands, analysed and reported for the Second National Soil Survey of Jiangxi in 1985 for the same soil sampling depth, were $12 \pm 4.8$ and $7 \pm 2.9 \mathrm{~g} / \mathrm{kg}$ for rice paddies and dry croplands, respectively (Q. Zhang, personal communication). However, in the present study, the household farmlands surveyed in 2003 had topsoil SOC contents of $14 \pm 5 \cdot 7$ and $8 \pm 5 \cdot 2 \mathrm{~g} / \mathrm{kg}$ for rice paddies and dry croplands, 
Table 3. Changes in farmland topsoil SOC $(\mathrm{g} / \mathrm{kg}$; mean $\pm S D$ ) with number and area of plots affiliated to the 15 surveyed households

\begin{tabular}{llll}
\hline \hline Item & \multicolumn{3}{c}{ Measurement value } \\
\hline $\begin{array}{l}\text { Number of plots occupied } \\
\text { Total area of farmland (ha) }\end{array}$ & $<0 \cdot 7$ & $\geqslant 0 \cdot 7$ & $\geqslant 0 \cdot 7$ \\
$\begin{array}{l}\text { Number of households } \\
\text { Household land }\end{array}$ & 6 & 7 & 2 \\
$\quad$ endowment (ha) & $0 \cdot 4 \pm 0 \cdot 06$ & $0 \cdot 9 \pm 0 \cdot 18$ & $1 \cdot 4$ \\
Topsoil SOC (g/kg) in 1985 & $12 \pm 2 \cdot 0$ & $10 \pm 1 \cdot 8$ & 11 \\
Topsoil SOC (g/kg) in 2003 & $13 \pm 2 \cdot 7$ & $17 \pm 1 \cdot 0$ & 9 \\
Mean SOC increase $(\mathrm{g} / \mathrm{kg})$ & $1 \pm 2 \cdot 1$ & $6 \pm 2 \cdot 0$ & -2 \\
\hline \hline
\end{tabular}

respectively (Fig. 4). The changes in deep profile with management practices seemed insignificant (Zhou et al. 2006) and were not taken into account in the present paper. There was an increase in topsoil SOC at 2.3 and $1.2 \mathrm{~g} / \mathrm{kg}$ of the surveyed plots, although the current level was lower than the provincial mean of $17 \pm 6 \cdot 2$ and $9 \pm 4.4 \mathrm{~g} / \mathrm{kg}$ reported by Huang (1999) for rice paddies and dry croplands, respectively.

The general trend of SOC increase in the present croplands by plot survey is in accordance with previous findings at the county level in Yixing (Zhang et al. 2004) and Wujiang (Hou et al. 2007) from the Tai Lake region, for Jiangsu province level (Liao et al. 2009) and across China's croplands (Pan et al. 2010). Greater SOC enhancement in rice paddies than in dry croplands has also been reported at the regional scale (Hou et al. 2007; Xu et al. 2009), and with long-term experiments (Wang et al. 2009, 2010) for generally higher inputs and lower decomposition under submerged conditions in rice paddies than in dry croplands. The mean rate of increase for rice paddies and dry croplands of 0.14 and $0.07 \mathrm{~g} / \mathrm{kg} / \mathrm{yr}$, respectively, are somewhat higher than those of $0 \cdot 11$ and $0.06 \mathrm{~g} / \mathrm{kg} /$ yr across China's croplands (Pan et al. 2010). This could be, in part, attributed to the chemical protection of SOC by binding to oxyhydrates in the soils derived from red earth (Zhou et al. 2009a). Zhou et al. (2009b) reported a faster and greater $\mathrm{C}$ sequestration in a redsoil-derived paddy under long-term experiments when comparing with other two rice paddy soils lower in free oxyhydrates.

However, higher increases have been reported for croplands from adjacent areas: Xu et al. (2009) showed mean increases of 0.25 and $0.09 \mathrm{~g} / \mathrm{kg} / \mathrm{yr}$ in rice paddies and dry croplands, respectively, at the county level in Guichi, Anhui Province, with predominantly lowland croplands derived mainly from wetlands along the Yangtze River. In a previous study, an increase in SOC of $0.28 \mathrm{~g} / \mathrm{kg} / \mathrm{yr}$ was observed during 1985-2002 in the rice paddies in Yixing County, Jiangsu Province (Zhang et al. 2004), where largerscale farms had been developed, and the cropping
Table 4. Topsoil SOC content (mean \pm S.D.) of plots with different agricultural management practices

\begin{tabular}{lcc}
\hline \hline $\begin{array}{l}\text { Crop and land } \\
\text { management }\end{array}$ & $\begin{array}{c}\text { Number } \\
\text { of plots }\end{array}$ & $\begin{array}{c}\text { Topsoil } \\
\text { SOC }(\mathrm{g} / \mathrm{kg})\end{array}$ \\
\hline $\begin{array}{l}\text { Cropping system } \\
\text { Single cropping }\end{array}$ & 24 & $9 \pm 6 \cdot 9$ \\
$\quad$ Double cropping & 47 & $13 \pm 5 \cdot 3$ \\
$\quad$ Triple cropping & 34 & $15 \pm 5 \cdot 7$ \\
Green manure & & \\
$\quad$ Cultivated & 34 & $15 \pm 5 \cdot 8$ \\
$\quad$ Non-cultivated & 71 & $11 \pm 5 \cdot 1$ \\
Straw return & & \\
$\quad$ Performed & 9 & $17 \pm 3 \cdot 9$ \\
$\quad$ Non-performed & 96 & $12 \pm 6 \cdot 1$ \\
\hline \hline
\end{tabular}

system of rice-rape and rice-winter fallow had been dominant since the late 1980s, with rapid industrialization (Ma \& Liu 2009). Thus, the increase in SOC of the surveyed household farmlands seemed comparatively smaller. This, together with variation of SOC contents with the different farm scales and plot sizes may reflect the impacts of land tenure arrangements and land fragmentation on cropland SOC storage and enhancement.

\section{Land tenure effects on cropland SOC in interaction with crop management}

The wide variation (Fig. 3, Tables 3 and 4) of plot topsoil SOC level reflected the interactive effects of agricultural management practices and household land management. Agricultural management practices had differing effects on topsoil SOC; the increases were: $29 \cdot 3 \%$ for green manure cultivation; $41.6 \%$ for straw return; $43.8 \%$ for rice cropping intensity $(16 \pm 5.4 \mathrm{~g} / \mathrm{kg}$ under double rice to $11 \pm 4.9 \mathrm{~g} / \mathrm{kg}$ under single rice); and $54.9 \%$ for total cropping intensity $(15 \pm 5 \cdot 7 \mathrm{~g} / \mathrm{kg}$ under triple cropping to $9 \pm 6.9 \mathrm{~g} / \mathrm{kg}$ under single crop, mainly of dry crops). In contrast, aspects of household land management showed land fragmentation to have an effect on topsoil SOC: plots over 0.1 ha had $19 \cdot 3 \%$ more SOC than plots smaller than $0 \cdot 1 \mathrm{ha}$; as did land use type: rice paddies had $72 \cdot 2 \%$ more SOC than dry croplands; and land tenure status showed land managed under direct contract had $96 \cdot 5 \%$ more SOC than leased land (Fig. 4). While the effects of land fragmentation on crop productivity and resource use efficiency have been widely debated (Wan \& Cheng 1996; Su \& Wang 2002; Tan et al. 2006, 2008), fragmentation was not a critical factor in the present study. A large reduction in SOC did occur when paddy was converted to dry cropland, which has also been observed elsewhere (Hou et al. 2007; Li et al. 2007). While agricultural management practices had direct effects on SOC 
through changes in organic matter input from the crop (especially with straw return and green manure cultivation), land tenure status had indirect effects through the above-mentioned organic matter input. Conservation practices have largely been neglected by the household farmers over the last decade (Wan \& Cheng 1996, 2001, 2005; Yu et al. 2003; Wang 2004; $\mathrm{Wu}$ et al. 2008). For leased farmlands, the land managers were more concerned with obtaining adequate yield rather than ensuring soil quality and fertility (Yu et al. 2003; Wu et al. 2008). In addition, most of the fragmented, small cropland plots in the village were the dry croplands on degraded red earth and with less accessible irrigation. Due to the relatively high cost of managing these fragmented lands of poor productivity, there is no incentive for the farmers to manage the land carefully (Tan et al. 2008). In fact, the fragmented, poor croplands some distance away from the village were those usually put for lease and used for dry crop production (Tan et al. 2008), which has resulted in reduced storage of SOC overall.

To examine the effect of good $v$. poor household and agricultural management, a subset of the plots was grouped into two extreme management scenarios. Scenario I consisted of 19 plots under double-cropped rice with straw return or green manure application, under direct contract and $>0 \cdot 1$ ha. Scenario II comprised 15 plots of dry croplands without green manure or straw return, under lease and $<0 \cdot 1$ ha. Land tenure and the agricultural management practices of croplands can have large synergistic effects on SOC storage. Storage of topsoil SOC was much smaller $(7 \pm 2 \cdot 10 \mathrm{~g} / \mathrm{kg}$ on average) in poorly managed plots (Scenario II) compared to those under the beneficial land use and management of rice paddies of Scenario I $(18 \pm 5 \cdot 3 \mathrm{~g} / \mathrm{kg}$ on average). This suggests a large gap in the SOC stock of farmlands due to household land management, which may thus have great impacts on SOC levels in China's croplands superimposing the agricultural management effects at farm scale.

Concern has been expressed previously that China's agriculture has been constrained by both the shortage of arable land and land fragmentation (Wan \& Cheng 1996; Su \& Wang 2002; Wu et al. 2005). The need for improved management to enhance cereal production and increase agricultural production efficiency has often been highlighted (Zhang \& Xu 1996; Luo 2008; Lu \& Zhang 2008; Wu et al. 2008; Jiang 2009; Ma \& Liu 2009). Management for enhancing crop productivity will benefit soil $\mathrm{C}$ sequestration (Lal 2004a), and organic C accumulation favours crop productivity in China's croplands, especially for rice paddies (Pan \& Zhao 2005; Pan et al. 2009a, b). Thus, developing a sound household land management system, in addition to good agricultural management practices, is necessary to help ensure cereal production, and $\mathrm{C}$ sequestration for mitigating GHG emissions in China. Therefore, incentives for encouraging good household farm management practices at the appropriate scale should be taken into account in China's national action plan for climate mitigation.

More broadly, the land tenure and household land management system seen in this region is very common throughout China, and has a number of similarities with systems in many other developing countries. The village studied was among those living on agricultural production in a rural area far from the cities (at least $150 \mathrm{~km}$ from the nearest city of Yingtang, Jiangxi as shown in Fig. 1). The size and total area, as well as the crop production, were typical for the south China's rural area; the mean size of total farmlands per household was $<1$ ha. Crop production was mainly rice, plus some dry crops in the rolling uplands with infertile soils. Most of the south Asian and African countries previously had such landform and agriculture as well as land tenure systems in rural areas (McPherson 1982; Otsuka et al. 2001; Suyanto et al. 2001; Niroula \& Thapa 2005; de Costa \& Sangakkara 2006). The present case study provides rare quantitative information linking limits in the efficacy in soil $\mathrm{C}$ storage with potential barriers to implementation, and may serve as a template for investigating barriers to implementation of climate mitigation practices in agriculture elsewhere in the developing world.

This work was a joint contribution from the Institute of Resource, Ecosystem and Environment of Agriculture and the China Centre for Land Policy Research, with which Genxing Pan acts as an adjunct professor and Shuyi Feng as a senior research scientist, of Nanjing Agricultural University. This study was partially supported by the Natural Science Foundation of China (NSFC) under grants 407100190002 and 70833001 . Project funding for the data synthesis from the Ministry of Education is also acknowledged. Pete Smith is a Royal Society-Wolfson Research Merit Award and a UK BBSRC China Partnership Award holder. Xuhui Zhang is a Visiting Research Fellow at the University of Aberdeen.

\section{REFERENCES}

CARter, M. R. (2002). Soil quality for sustainable land management: organic matter and aggregation interactions that maintain soil functions. Agronomy Journal 94, $38-47$.
De Costa, W. A. J. M. \& Sangakkara, U. R. (2006). Agronomic regeneration of soil fertility in tropical Asian smallholder uplands for sustainable food production. Journal of Agricultural Science, Cambridge 144, 111-133. 
Eitzinger, J., Orlandini, S., Stefanski, R. \& NAYlor, R. E. L. (2010). Climate change and agriculture: introductory editorial. Journal of Agricultural Science, Cambridge 148, 499-500.

García-Oliva, F. \& Masera, O. R. (2004). Assessment and measurement issues related to soil carbon sequestration in land use, land use change, and forestry (LULUCF) projects under the Kyoto Protocol. Climatic Change 65, 347-364.

Gong, Z. T., Zhang, G. L. \& Chen, Z. C. (2007). Pedogenesis and Soil Taxonomy. Beijing: China Science Press (in Chinese).

Grandy, A.S. \& Robertson, G. P. (2007). Land use intensity effects on soil $\mathrm{C}$ accumulation rates and mechanisms. Ecosystems 10, 58-73.

Guo, L. B. \& Gifford, R. M. (2002). Soil carbon stocks and land use change: a meta analysis. Global Change Biology 8, 345-360.

Hou, P. C., Xu, X. D. \& PAN, G. (2007). Influence of land use change on topsoil organic carbon stock a case study of Wujiang Municipality. Journal of Nanjing Agricultural University 32, 68-72 (in Chinese with English summary).

Huang, G. Q. (1999). Cropland resources and the sustainable use of Jiangxi. Acta Agriculturae Jiangxi 11 (Suppl.), 48-53 (in Chinese).

JIANG, D. Y. (2009). Five issues of developing proper scale up farmland management. Rural Economy of Jiangsu 2009, 21-24 (in Chinese).

JiAngXi Bureau of Land Management (JBLM) (1991). Soils of Jiangxi. Beijing: China Agricultural Science \& Technology Publishing House (in Chinese).

Kuiper, M., Heerink, N., Tan, S., Ren, Q. \& Shi, X. (2001). Report of Village Selection for the Three Village Survey. Wageningen, The Netherlands: Wageningen University.

LAL, R. (2002). Soil carbon sequestration in China through agricultural intensification, and restoration of degraded and desertified ecosystems. Land Degradation and Development 13, 469-478.

LAL, R. (2004a). Soil carbon sequestration impacts on global climate change and food security. Science 304, 1623-1627.

LAL, R. (2004b). Offsetting China's $\mathrm{CO}_{2}$ emissions by soil carbon sequestration. Climatic Change 65, 263-275.

Lewandrowski, J., Peters, M., Jones, C., House, R., Sperow, M., Eve, M. \& Paustian, K. (2004). Economics of Sequestering Carbon in the U.S. Agricultural Sector. Technical Bulletin No. TB-1909. Washington, DC: Economic Research Service, USDA.

Li, Z. P., PAN, G. \& Zhang, X. H. (2007). Topsoil organic carbon pool and $13 \mathrm{C}$ natural abundance changes from a paddy after 3 years corn cultivation. Acta Pedologica Sinica 44, 244-251 (in Chinese with English summary).

Liao, Q. L., Zhang, X. H., Li, Z. P., Pan, G., Smith, P., JIN, Y. \& WU, X. M. (2009). Increase in soil organic carbon stock over the last two decades in China's Jiangsu Province. Global Change Biology 15, 861-875.

Lu, R. K. (2000). Analytical Method of Soil Agricultural Chemistry. Beijing: China Agricultural Science and Technology Press (in Chinese).

Lu, R. S. \& ZHANG, Y. X. (2008). The problem of increasing sustainably the income from agriculture for China's farmers. Agriculture Rural Economy 6, 26-27 (in Chinese).

LuO, Q. (2008). Factors influencing proper scale up management in China's agriculture. Economic Research Guide 2008, 12-13 (in Chinese).
MA, K. P. \& LiU, Y. (2009). Proper scale up land management: a necessity option for modern China's agriculture. Rural Economy of Jiangsu 2009, 14-16 (in Chinese).

McPherson, M. (1982). Land Fragmentation: a Selected Literature Review. Development Discussion Paper, No. 141. Cambridge, MA: Harvard Institute for International Development, Harvard University.

Milne, E., Paustian, K., Easter, M., Sessay, M., Al-Adamat, R., Batjes, N.H., Bernoux, M., Bhattacharyya, T., Cerri, C. C., Cerri, C. E. P., Coleman, K., Falloon, P., Feller, C., Gicheru, P., Kamoni, P., Killian, K., Pal, D. K., Powlson, D.S., Williams, S. \& RawaJfih, Z. (2007). An increased understanding of soil organic carbon stocks and changes in non-temperate areas: national and global implications. Agriculture, Ecosystems and Environment 122, 125-136.

National Agricultural Census Office of China (NACOC) AND Food and Agricultural Statistics Census, China (FASC). (1999). Abstract of the First National Agricultural Census in China. Beijing: China Agriculture Press. (In Chinese).

Niroula, G. S. \& Thapa, G. B. (2005). Impacts and causes of land fragmentation, and lessons learned from land consolidation in South Asia. Land Use Policy 22, 358-372.

Ogle, S. M., Breidt, F. J. \& Paustian, K. (2005). Agricultural management impacts on soil organic carbon storage under moist and dry climatic conditions of temperate and tropical regions. Biogeochemistry 72, 87-121.

Osher, L. J., Matson, P. A. \& Amundson, R. (2003) Effect of land use change on soil carbon in Hawaii. Biogeochemistry 65, 213-232.

Otsuka, K., Suyanto, S., Sonobe, T. \& Tomish, T. P. (2001). Evolution of land tenure institutions and development of agroforestry: evidence from customary land areas of Sumatra. Agricultural Economics 25, 85-101.

Ou-YANG, J. L., Yu, Z. R. \& Zhang, F. R. (2003). The study of the change of soil quality and the analysis of farm household based on eco-economy zone. Acta Ecologica Sinica 23, 1147-1155 (in Chinese with English summary).

PAN, G. X. (2009). Stock, dynamics of soil organic carbon of China and the role in climate change mitigation. Advance in Climate Change Research 5 (Suppl.), 11-18.

Pan, G. X., Li, L. Q., Wu, L. S. \& Zhang, X. H. (2004). Storage and sequestration potential of topsoil organic carbon in China's paddy soils. Global Change Biology $\mathbf{1 0}$, 79-92.

PAN, G. X., Smith, P. \& PAN, W. N. (2009a). The role of soil organic matter in maintaining the productivity and yield stability of cereals in China. Agriculture, Ecosystems and Environment 129, 344-348.

Pan, G. X., Xu, X. W., Smith, P., Pan, W. N. \& Lal, R. (2010). An increase in topsoil SOC stock of China's croplands between 1985 and 2006 revealed by soil monitoring. Agriculture, Ecosystems and Environment 136, 133-138.

PAN, G. X. \& ZHAO, Q. (2005). Study on evolution of organic carbon stock in agricultural soils of China: facing the challenge of global change and food security. Advances in Earth Science 20, 384-393 (in Chinese with English summary).

Pan, G.X., Zhou, P., Li, Z. P., Smith, P., Li, L. Q., Qiu, D.S., Zhang, X. H., Xu, X. B., Shen, S. G. \& CHEN, X. M. (2009b). Combined inorganic/organic fertilization enhances $\mathrm{N}$ efficiency and increases rice 
productivity through organic carbon accumulation in a rice paddy from the Tai Lake region, China. Agriculture, Ecosystems and Environment 131, 274-280.

RAHMAN, S. \& RAHMAN, M. (2009). Impact of land fragmentation and resource ownership on productivity and efficiency: the case of rice producers in Bangladesh. Land Use Policy 26, 95-103.

Schlamadinger, B., Bird, N., Johns, T., Brown, S., Canadell, J., Ciccarese, L., Dutschke, M., Fiedler, J., Fischlin, A., Fearnside, P., Forner, C., Freibauer, A., Frumhoff, P., Hoehne, N., Kirschbaum, M. U. F., Labat, A., Marland, G., Michaelowa, A., Montanarella, L., Moutinho, P., Murdiyarso, D., Pena, N., Pingoud, K., Rakonczay, Z., Rametsteiner, E., Rock, J., SAnz, M. J., Schneider, U.A., Shvidenko, A., Skutsch, M., Smith, P., Somogyi, Z., Trines, E., WARd, M. \& Yamagata, Y. (2007). A synopsis of land use, land-use change and forestry (LULUCF) under the Kyoto Protocol and Marrakech Accords. Environmental Science and Policy 10, 271-282.

Simmons, S. R. (1986). Land fragmentation in developing countries: the optimal choice and policy implications. In Agriculture in a Turbulent World Economy: Proceedings of the 19th International Conference of Agricultural Economists, Malaga, Spain, 26 Aug-4 Sep 1985 (Eds A. Maunder \& U. Renborg), pp. 703-716. London: Gower Publishing Company.

Smith, O. H., Petersen, G. W. \& Needelman, B. A. (1999). Environmental indicators of agro-ecosystems. Advances in Agronomy 69, 75-97.

SMITH, P. (2008). Land use change and soil organic carbon dynamics. Nutrient Cycling in Agroecosystems 81, 169178.

Smith, P., Martino, D., Cai, Z., Gwary, D., Janzen, H., Kumar, P., McCarl, B., Ogle, S., O'Mara, F., Rice, C., Scholes, B., Sirotenko, O., Howden, M., McAllister, T., Pan, G.X., Romanenkov, V., Schneider, U. \& Towprayoon, S. (2007). Policy and technological constraints to implementation of greenhouse gas mitigation options in agriculture. Agriculture, Ecosystems and Environment 118, 6-28.

Smith, P. \& Trines, E. (2007). Agricultural measures for mitigating climate change: will the barriers prevent any benefits to developing countries? International Journal of Agricultural Sustainability 4, 173-175.

Soll Survey Office of Yujiang County (SSOYC). (1986). Soils of Yujiang County: A Soil Survey Report. Yujiang, Jiangxi: SSOYC (in Chinese).

Soll Survey Staff, USDA (SSS-USDA) (1999). Soil Taxonomy: a Basic System of Soil Classification for Making and Interpreting Soil Surveys. Washington, D.C.: Natural Resources Conservation Service, USDA-ARS.

Song, G. H., Li, L. Q., PAN, G. X. \& Zhang, Q. (2005). Topsoil organic carbon storage of China and its loss by cultivation. Biogeochemistry 74, 47-62.

SPSS (2001). SPSS Base 11 for Windows: User's Guide. Englewood Cliffs, NJ: Prentice-Hall.

Su, X. X. \& WANG, X.Q. (2002). Land fragmentation and grain production: a case study of Laixi City, Shandong Province, China. China Rural Economy 4, 22-28 (in Chinese).

Suyanto, S., Thomas, P. T. \& Otsuka, K. (2001). Land tenure and farm management efficiency: the case of paddy and cinnamon production in customary land areas of Sumatra. Australian Journal of Agricultural and Resource Economics 45, 411-436.

Tan, S., Heerink, N., Kruseman, G. \& Qu, F. (2008). Do fragmented landholdings have higher production costs? Evidence from rice farmers in Northeastern Jiangxi province, P.R. China. China Economic Review 19, 347-358.

Tan, S., Heerink, N. \& Qu, F. (2006). Land fragmentation and its driving forces in China. Land Use Policy 23, 272-285.

WAN, G. H. \& Cheng, E. (2001). Effects of land fragmentation and returns to scale in the Chinese farming sector. Applied Economics 33, 183-194.

Wan, G. H. \& Cheng, E. J. (1996). China's cereals production with scaling and land fragmentation. China Rural Survey 3, 31-36 (in Chinese).

WANG, C.J., PAN, G.X. \& Tian, Y.G. (2009). Characteristics of cropland topsoil organic carbon dynamics under different conservation tillage treatments based on long-term agro-ecosystem experiments across mainland china. Journal of Agro-Environment Science 28, 2464-2475 (in Chinese).

Wang, C. J., Pan, G.X., Tian, Y.G., LI, L. Q., ZhANG, X. H. \& HAN, X. J. (2010). Changes in cropland topsoil organic carbon with different fertilizations under long-term agro-ecosystem experiments across mainland China. Science China: Life Sciences 53, 858-867.

WANG, G. X. (2004). From the household responsibility to modern farm company for farmland management of China. Northern Economy 2004, 11-13 (in Chinese).

WANG, Y. \& CHEN, Z. J. (2005). The instrumental gap of the household responsibility of farmland managements of China. Modern Science and Technology of Agriculture 11, 91 (in Chinese).

Wu, H., Miao, Y. H., Jiang, H., Xu, D. \& Jiao, W. P. (2008). Improving the circulation market of land contractual management rights for land operation with proper scale-up. China Agricultural Science Bulletin 24, 547-550 (in Chinese).

Wu, Z., Liu, M. \& Davis, J. (2005). Land consolidation and productivity in Chinese household crop production. China Economic Review 16, 28-49 (in Chinese).

Xu, Q., Rui, W. Y., He, H., Wu, F., Luo, H., Bian, X. M. \& ZHANG, W. J. (2006). Characteristics and regional differences soil organic carbon density in farmland under different land use patterns in China. Scientia Agricultura Sinica 39, 2505-2510 (in Chinese with English summary).

Xu, X. W., Pan, G. X. \& Sun, X. L. (2009). Changes in topsoil organic carbon content and the significance in $\mathrm{C}$ sequestration of farmlands from Guichi County, Anhui Province, China. Journal of Agro-Environmental Science 28, 2551-2558 (in Chinese with English summary).

Yu, H., Huang, J., Scott, R., Brandt, L. \& Zhang, L. (2003). Use rights security, land transfer and resource degradation. Economic Research Journal 9, 82-91 (in Chinese).

Zhang, L.X. \& Xu, X. M. (1996). Farm household behaviour in production under different policy environment. Journal of Agro-Technological Economy 4, 27-32 (in Chinese).

Zhang, Q., Li, L. Q., Pan, G. X., Wang, H. G., Jiang, A. D. \& HuAnG, H. G. (2004). Dynamics of topsoil organic 
carbon of paddy soils at Yixing over the last 20 years and the driving factors. Quaternary Sciences 24, 236-242 (in Chinese with English summary).

Zhaо, Q. G. (2002). The Red Soil Material Cycling and its Regulation. Beijing: China Science Press (in Chinese with English summary).

Zhou, P., Song, G. H., Pan, G., Li, L. Q. \& Zhang, X. H. $(2009 a)$. Role of chemical protection by binding to oxyhydrates in SOC sequestration in three typical paddy soils under long-term agro-ecosystem experiments from South China. Geoderma 153, 52-60.
Zhou, P., Pan., G. X., Li, L. Q. \& Zhang, X. H. (2009b). SOC enhancement in major types of paddy soils in a long-term agro-ecosystem experiment in South China. V. Relationship between carbon input and soil carbon sequestration. Scientia Agricultura Sinica 42, 4260-4268.

Zhou, P., Zhang, X.H. \& PAN, G. X. (2006). Effects of longterm different fertilizations on total and particular organic carbon and the depth distribution a rice soil from Tai Lake region, Jiangsu, China. Plant Nutrition and Fertilizer Sciences 12, 765-771 (in Chinese with English summary). 